\title{
A Comparative Analysis of Activity Based Learning on Male and Female Students
}

\section{Achievement Inlistening Skill at Grade-VI}

\author{
* Zahoor-ul-Haq, Lecturer (Corresponding Author) \\ ** Bushra Ahmed Khurram, Assistant Professor \\ *** Muhammad Khalil, Lecturer
}

\begin{abstract}
This paper reports on a study that investigates the effect of activity-based learning on the listening skills of male and female students' achievement. It also considers the differences in the achievement of male and female students of grade VI. The study had a pre-test and post-test equivalent group design. A sample of 120 students was selected randomly from boys' and girls' schools of district Nowshera. In both gender schools, control and experimental groups were made. Each group consisted of 30 students. The experimental groups were instructed through activity-based learning, whereas the control groups were taught with the traditional method of language teaching. A total of four teachers, two from each gender school, were selected for teaching the assigned groups. A posttest was conducted at the end of the experiment in both groups. The results of the study showed that the experimental groups performed better than control groups in the listening test. Moreover, no significant difference was found between the achievements of boys and girls in experimental groups. The study recommends that professional teacher training courses should introduce and promote activity-based learning.

Keywords: Second Language, Activity-Based Learning, Listening, Language Skills

\section{Introduction}

English in Pakistan stands as a second language (Mashori 2010). Because English is equated with economic prosperity in Pakistan, English language teaching has remained a forefront agenda of successive elected governments (Khurram, 2016). Currently, English is taught from grade 1 as a subject (Government of Pakistan 2009). However, the majority of students studying in public sector educational institutes have low levels of proficiency in English (Memon \& Badger 2007). One of the reasons behind this is that majority of teachers, especially in public sector institutes, find it difficult to teach English as they lack the prerequisite training in teaching it (Khurram, 2007). Besides, the majority of public sector schools use the grammar-translation method for teaching English that focuses only on the teaching of grammar and ignores listening and speaking skills. Needless to say, public sector schools are producing students who lack proficiency in English language skills. With this in view, the current study focused on teaching of listening skills and investigated the role of activity-based learning (henceforth, ABL) in the development of listening skills.
\end{abstract}

\section{Listening}

Listening is an important component of language learning. The Second Language Acquisition (SLA) studies have shown that comprehension and comprehensible production are essential to language acquisition (Swain, 1995). It is therefore important to consider the characteristics of an effective listening text for language learning courses. Literature indicates that several factors affect the quality of a listening text. However, broadly speaking, the quality of a text can usually be divided into two categories: content and delivery. In terms of its 'content', the listening test must be interesting to the students. For this, it is important to know the profile of target students because what interests one

\footnotetext{
* Department of Education, Bacha khan University, Charsadda. Email: zahoorulhaq@bkuc.edu.pk

** Department of English, University of Karachi. Email: bushrakhurram@yahoo.com

*** FG boys College, Risal Pur Nowshera Email: khalilmathematics1977@gmail.com 
learning group might be boring for another group. In a teaching lesson, pre-assignment activities are designed to engage students in the core activity.

Cultural accessibility is also a decisive factor in successful listening. Learning a new culture is beneficial for improving intercultural competence (Wilson, 2008), but if the goal is to understand a listening text, any meaning in the text, based on culture, must be understandable to the target audience. The density of the audio also influences the audio quality. If the text contains repetition of keywords, words, and phrases, it is less demanding for the listener. The more complex are the grammatical structures of the text, the more demanding they become for listeners. In addition to the content, the presentation of the material is equally important as well. Concerning 'delivery', the important factors are the length, the quality of the material, the approach and the method of delivery. Besides, the sound must also be equally distributed and adapted by the target group of students (Wilson, 2008).

Imagine that you arrive too late in class and notice that the teacher has already started teaching. It is probably difficult for you to understand the subject and the happening. Why do you think that will happen? Since you do not know the context, the context is initially inaccessible. Therefore, the goal of preschool activities is to let students know what they need to know before listening. Reviewers should be familiar with things such as speaker talk, length of the text, function, subject information, subject vocabulary, and the speaker-speaker relationship (Wilson, 2008). A study by Zohrabi et al. (2015) states that students who are active before listening perform better than those who are not. They also say that preschool homework is effective in helping students understand authentic English film

In listening assessment, the activities are directly related to the sound and students perform the task either while listening or immediately after it. Therefore, the teacher must coordinate the activities for learning, achieving listening objectives, and enabling the students to perform better. Underwood (1989) explains that the purpose of listening tasks helps students understand the text messages. Well-designed listening activities help students understand the audio, identify the key elements, and become attentive to understand the structure of the text (Wilson, 2008). Bingo is an example of the activity heard. This activity is particularly enjoyable for young people. In this task, the teacher writes a list of words from the listening stimulus on the board. Students individually choose seven words and write them one by one on a piece of paper. Then they listen to the passage and mark those words as they hear them. When all the words are highlighted, they call "Bingo". This is a good activity for selective hearing, though it is very damaging to hearing (Wilson, 2008).

After listening, students work in detail using top-down and bottom-up strategies to link lesson activities to real-life (Wilson, 2008). Underwood (1989) describes it as an activity after the interception, combining all the work done. Post-listening activities can be directly related to previous or previous activities or simply to these activities. He also explains that follow-up activities take longer than other tasks because students control the processes of reflection, discussion, and writing. This can be described as the most reflective part of the lesson. "Check and summarize" is a type of activity that can be performed later. In this activity, the teacher first places students in small groups to reduce their fears. The role of the teacher is to supervise and stimulate students by drawing attention to related and interesting issues. They share their ideas in class and summarize the important parts. Other types of post-listening activities include discussions, creative responses, critical responses, information sharing, problem-solving, deconstruction of listening text, and reconstruction of the listening text (Wilson, 2008).

Although language teaching has recently become more important for language courses, the learning and teaching of these interactive skills have changed paradigms. Listening is now seen as an interactive and not passive skill because the human brain is active during this process. A student consciously receives the new data, analyses it, and uses it. In this process, he uses metacognitive, cognitive, and effective strategies. Researchers agree that metacognition improves thinking and understanding (Vandergrift, 2012). As a result, students who plan, monitor, and evaluate their listening process are listeners or language learners who perform better than those who do not. In the new trend, students' metacognitive awareness should be increased which can also increase students' motivation to succeed (Khurram, 2016). 
Due to the new trend, attention has also been given to understanding the details and essence of messages with a communicative purpose. In other words, text-oriented instructions that consist of decoding, imitating, storing and distinguishing sound and grammar diagrams, and answer comprehension questions based on a listening stimulus, leave room for communicative training of the learner. There is a tendency to know how students listen and manage their autonomy. Teachers should conduct activities before communication to educate students about the listening process. Besides, Richards (2005) suggests that the activities should allow students to perform an active part in their learning. In the context of communicative teaching, listening, speaking, reading, and writing are taught in several lessons in which students can practice each skill in the subject. In communicative education, listening activities are mainly used to provide basic knowledge and enhance vocabulary. Another change in listening was the emphasis on the top-down approach rather than the bottom-up approach. The basic information in the mind of the listener, especially at the beginning of a listening activity, the listening abilities concerning the discrimination of individual tones are to be improved. It is also emphasized that listening should be considered as a process rather than a product (Vandergrift, 2007). Listening must be understood from beginning to end as an active process of meaning construction.

Richards (2005) suggests that the listening material should be based on a variety of authentic texts. In other words, the listening material used in real life makes listeners motivated to achieve communication goals because language is a social phenomenon and authenticity is an important factor of it. Platforms like Network-based multimedia applications, i.e. online audio and video, YouTube, podcasts, and blogs offer a variety of ways to achieve real-life communication goals. Students have two goals: understanding and acquisition. Although learning to listen involves understanding the linguistic process, listening means learning to create a new meaning and a new form, i.e. to reestablish the connection between meaning and meaning, thus helping students to be more cautious about the syntax and vocabulary of the language by listening. Therefore, teachers should consider listening skills as a way to improve language acquisition (Kurita, 2012).

\section{Activity Based Learning}

Prince (2004) states that ABL is a teaching method in which students take an active role in the lesson. Along similar lines, Harfield et al. (2007) state that ABL is a teaching method in which students, unlike being non-receptive viewers, actively contribute to all learning activities. Hein (1991) opines that $\mathrm{ABL}$ has roots in the constructivist theory of learning. Constructivists are of the view that in the act of learning, each person builds personal knowledge of the learning process and links it with their background knowledge. Likewise, constructivist theory stipulates that learning occurs when the background knowledge of the learner is associated with an exact construction. Hence, for the construction of knowledge, learners must encounter different activities in classes (Abdelhamid 2003, Murray et al., 2004).

Edward (2001) indicates that activities that provide practical life experiences to learners can facilitate the conversion of the information into individual knowledge which then can be brought into use on different occasions. Advocating the use of activity-based learning, Harfield et al. (2007) asserts that an active approach to language learning differs from the conventional approach on two grounds; first, it encourages active engagement of the student, second, it enhances cooperation between the students. Put another way, ABL requires learners to actively participate in practical actions and see other people performing practical tasks (Suydam et al., 1997).

Churchill's (2003) study found that activity-based learning helps learners in creating and reinforcing their intellectual level and allows a higher reasoning capacity to increase their abilities, for example; virtually solving the problem; and transferring of knowledge and skills. Kolb's (1984) study reveals that conventional teaching methods are not suitable for practical learning because demonstrative learning means uniform practices with a maneuver of resources. Domin (2007) asserts that in constructivism, teachers cannot transform successful learning into learners if they are not familiar with the activity. Hull (1999) has shown that a large number of learners in our schools are not able to practically use the knowledge they gain in the classrooms. There are several reasons. However, the chief reason among them is learners' inability to contextualize their learning method. $\mathrm{ABL}$ is considered as a useful way of contextualizing the students' learning process. 
Chickering and Gamson (1987) believe that learners should converse and write about the things they learn and the tasks they do in the class. Besides, learners may also need to link it with past experiences and also use it in their daily lives. Hug et al. (2005) felt that learners showed a strong interest in learning that incorporates real-world tasks.

Churchill's (2003) study indicates that in ABL, students scrutinize learning needs and think about solving the problems they face. This shows that activity-based learning drives students towards problem-solving. The process of solving the problem helps them encounter new knowledge of the subject. However, without learners' motivation, successful uptake of teaching and learning is not possible. Besides, Hake's (1998) study shows that learners' willingness to participate in activities is valuable in teaching complex ideas. Cabral (2006) states that practical learning is more common in higher education. Teaching plans that include hands-on learning can increase learner involvement in the teaching and learning process.

\section{Objectives of the Study}

a) To study the effect of activity-based learning on male students' achievement in listening skills in class six.

b) To find the effectiveness of activity-based learning on female students' achievement in listening skill at Grade-VI

c) To compare the achievement of male and female students in listening skill at Grade-VI

\section{Hypotheses}

Null hypotheses were tested for this study.

\section{Significance of the Study}

Pakistan is striving hard for the improvement of the education system. Therefore diverse methods are used to make the teaching more effective especially for teaching English. The present study is also an effort to find the effectiveness of activity-based learning to find another useful method for the enhancement of listening skills. Therefore, this study will be very useful for language teachers. In this way, they will be familiar with a new method which can be implemented by them in their language classrooms. Researchers will get benefit from this study also. They may proceed with further researchers in the areas which are not done. This study will be of great importance for the curriculum developers. Policymakers may plan as per the requirement of the study.

\section{Methodology}

\section{Research Design}

According to Kerlinger (1973), research design consists of the research structure and techniques that are applied to conduct research. The design of the current study was a pre-test and post-test equivalent group. Thompson et al. (2006) state that although refinements are consistently developed, the basic experimental design has been constant for many years and is regarded as a "gold standard" with which other designs are measured.

\section{Population}

All the male and female students studying in grade-VI in public sector schools were the population of this study.

\section{Sample}

Campbel et al. (1963) mention that if the groups are selected randomly, they may be called as equivalent. A total of 120 boys and girls were selected as a sample for this study. First, 60 girls of grade VI were selected randomly from government girls' high school Tarka as a sample. This is followed by a pre-test taken from them. After the collection and marking of the pre-test, two groups, i.e. experimental and control groups were made ensuring that those who secured the highest marks were distributed into two groups. The process continued in the same way until the distribution of the last student in both groups. In this way, two equivalent groups in terms of language proficiency were formed. The same process was repeated for the selection and distribution of boys. Each of the four groups consisted of 30 students.

\section{Research Instrument}

Pre-test and post-test was used as a research instrument in the present study. The first author developed a pre-test that consisted of 50 items as per the level of students. The listening instructions of IELTS and TOEFL were incorporated in the test. To develop a reliable and valid test, many educationists and language experts were consulted via email and in person. Keeping their viewpoints, 
item no $3,8,15,20,21,34,37,39,40,44$ and 46 were changed because of their validity and difficulty level.

Some listening stimuli were delivered by audio recording while the remaining stimuli were verbally conveyed by the teachers. Based on the passage, the students answered the questions by selecting the correct option from the given options. Five passages were read to the students. The time allotted to the test was two hours. The selected passages were based on the following topics: (a) Ibn-e-Seena; (b) Overpopulation in cities; (c) The Cub; (d) Electricity, and (e) Qissa Khwani Bazar. The post-test consisted of the same 50 items but with a different item sequence.

\section{Procedure}

The present study was introduced to the principals of both girls and boys Government High Schools and permission was granted to conduct the study. The schools agreed to facilitate the process by cooperating with the research teachers. For the study, the four selected research teachers, 2 males and 2 females, were trained by language experts for a week.

After the training of one week, the first author visited the boys' school and conducted a pretest. The sample students were facilitated in the process. The test consisted of 50 multiple choice items, making up to 50 marks. Half of the listening stimuli were audio-recorded and played to students one by one while the other halves were read verbally. After the given time of 2 hours, the test was collected from the students. At the end of the test, refreshment was provided to the participants.

The same process was conducted the next day at Government Girls High School Tarka. The pre-test was administered and collected from girls. The test was then checked and marked. Based on the scores obtained, students were distributed into four groups. Four groups were formed based on pre-test scores. For the study, listening activities were developed for different stages of listening by the researcher. Pre-listening, while listening and post-listening activities were also taken from the British Council's 'Learn English' website. Besides that, lesson plans for seven weeks were also developed and shared with foreign and local language experts. The lesson plans based on listening activities were provided to teachers of the experimental group who were trained before the commencement of the experiment. In contrast, the control groups were taught with the conventional teaching method. The researcher, however, requested teachers to give their best even while teaching conventionally. The experiment continued for seven weeks. It was done under the supervision of the researcher who guided the teachers as and when required. After seven weeks, a post-test was administered to reach the findings of the present study.

Validity and Reliability

Once the instrument was developed, the validity of the test was checked. For this purpose, a pilot study was conducted in a Government Middle school Khushmuqam. The test was taken by a sample of 20 sixth grade students, randomly selected, to check its language and difficulty level. The audio recorded and verbally read listening stimuli were delivered to the students one by one. To keep the pace of teachers similar to the ones in audio recording, a medium speed was maintained as per the level of the listeners. The split-half method was used to check the reliability of the test, which was 0.79. The pilot study helped make the pre-test standardized.

\section{Data Collection}

For data collection, pre-test and post-test were developed.

Data Analysis

To analyze the data, SPSS 20 version and applied t-test for independent samples were used. The Analysis was done twice to minimize errors and mistakes.

Analysis and Interpretation of Data

Table1: pre-test score of boys Experimental and Control groups

\begin{tabular}{lccccc}
\hline \multicolumn{1}{c}{ Group } & N & Mean & $\begin{array}{c}\text { Std. } \\
\text { Deviation }\end{array}$ & Table value & $\begin{array}{c}\text { t-value } \\
\text { Calculated value }\end{array}$ \\
\hline Experimental (Boys) & 30 & 16.033 & 1.847 & 1.677 & 0.601 \\
Control (Boys) & 30 & 15.733 & 2.016 & & Significance level $=0.05$ \\
\hline Degree of freedom $=58$ & \multicolumn{2}{c}{ *Not Significant } & &
\end{tabular}

Table No 1 shows that there were 30 students in each experimental and control group. The mean of the experimental group was 16.033 while the mean of the control group was 15.733. Furthermore, as 1.847 was the std. deviation of the experimental group was, the std. deviation of the 
control group was 2.016. Besides, the calculated and table value of $t$ were 0.601 and 1.677 respectively at the 0.005 level of significance. It shows that the calculated value of $t$ was less than the table value.

It is evident from the results that no significant difference was found between the two groups regarding achievement in listening skills and both the groups could be considered as equal in proficiency level.

Table2: Pre-test score of Girls Experimental \& Control groups

\begin{tabular}{lccccc}
\hline \multicolumn{1}{c}{ Group } & N & Mean & $\begin{array}{c}\text { Std. } \\
\text { Deviation }\end{array}$ & Table value & $\begin{array}{c}\text { t-value } \\
\text { Calculated value }\end{array}$ \\
\hline Experimental (Girls) & 30 & 14.333 & 3.155 & 1.677 & 0.000 \\
Control (Girls) & 30 & 14.333 & 3.155 & & \\
\hline
\end{tabular}

Degree of freedom $=58 \quad$ *Not Significant level of significance $=0.05$

Table No. 2 shows similar mean values of both groups, i.e. 14.333. Not only this, both the groups had the same std. deviation of 3.1555. While the calculated value of $t$ was 0.000 , the table value was 1.677 with the 0.005 level of significance. Again, the calculated value of $t$ was less than the table value and no significant difference in the achievement of listening skills was found between the two groups. It is safer, therefore, to say that both groups had the same proficiency level.

Table3: Post-test score of male Experimental and Control groups

\begin{tabular}{lccccc}
\hline \multicolumn{1}{c}{ Group } & N & Mean & $\begin{array}{c}\text { Standard } \\
\text { Deviation }\end{array}$ & Table value & $\begin{array}{c}\text { t-value } \\
\text { Obtained value }\end{array}$ \\
\hline $\begin{array}{l}\text { Experimental (Boys) } \\
\text { Control(Boys) }\end{array}$ & 30 & 26.666 & 1.028 & 1.677 & $13.921^{*}$ \\
\hline Degree of freedom=58 & 30 & 17.7000 & 3.374 & & \\
\hline
\end{tabular}

Table No 3 shows an evident difference in the mean values of both groups, i.e. 26.666 in the experimental group and 17.700 in the control group. Similarly, while the std. deviation of the experimental group was 1.028, it was 3.374 in the control group. The calculated and the table value of $\mathrm{t}$ were 13.921 and 1.677 respectively with the 0.005 level of significance. This time the calculated value of $\mathrm{t}$ was greater than the table value and therefore, there was a significant difference in the achievement of the two groups. The male students who were exposed to activity-based learning performed better in the post-test as compared to those in the control group. The activity-based learning method, therefore, proved to be better than the routine method of language teaching.

Table4: Post-test female experimental \& control groups

\begin{tabular}{|c|c|c|c|c|c|}
\hline \multirow{2}{*}{ Group } & \multirow{2}{*}{$\mathbf{N}$} & \multirow{2}{*}{ Mean } & \multirow{2}{*}{ Standard Deviation } & \multicolumn{2}{|c|}{ t-value } \\
\hline & & & & Table value & Obtained value \\
\hline Experimental (Girls) & 30 & 27.200 & 2.107 & 1.677 & $11.086^{*}$ \\
\hline Control (Girls) & 30 & 15.933 & 5.152 & 1.071 & \\
\hline
\end{tabular}

As is evident from the table, the mean value of the experimental group was 27.200. In contrast, the control group had a mean value of 15.933. Furthermore, the std. deviation of the experimental group was 2.107 while it was 5.152 in the control group. The calculated value and the table value of $\mathrm{t}$ were 11.086 and 1.677 at the 0.005 level of significance. The fact that the calculated value of $t$ was greater than the table value, there was a significant difference found between the two groups regarding the achievement in listening skills. The female students who were taught through activity-based learning comparatively performed better in the post-test than those in the control group. It further reinforced that the activity-based learning method is better than the routine method of language teaching.

Table5: Comparison of Post-test scores of Girls and Boys of Experimental groups

\begin{tabular}{|c|c|c|c|c|c|}
\hline \multirow{2}{*}{ Group } & \multirow{2}{*}{$\mathbf{N}$} & \multirow{2}{*}{ Mean } & \multirow{2}{*}{ Standard Deviation } & \multicolumn{2}{|c|}{ t-value } \\
\hline & & & & Table value & Obtained value \\
\hline Experimental Girls & $\begin{array}{l}30 \\
30\end{array}$ & $\begin{array}{l}27.200 \\
26.667\end{array}$ & $\begin{array}{l}2.107 \\
1028\end{array}$ & 1.677 & 1.246 \\
\hline
\end{tabular}

Degree of freedom $=25 \quad$ level of Significance $=0.05$

*Not Significant 
Table No 5 shows that the mean value of the experimental group was 27.200 while it was 26.667 in the control group. Moreover, the std. deviations of the two groups were 2.107 and 1.028 respectively. The calculated value of $t$ was found to be 1.246 , whereas, the table value of $t$ was 1.677 at the 0.005 level of significance. Because the calculated value of $t$ was less than the table value, no significant difference in the achievement of the two groups was found. Since both boys and girls were instructed through activity-based learning, it also shows no significant differences in the achievement of the two gender groups.

\section{Discussion}

The analysis of the pretest score showed that the experimental and control groups of boys were almost at a similar level of achievement in listening. Likewise, the pretest score of the experimental and control groups of girls yielded the same results. Put another way, students of both groups had almost a similar acquisition level in listening. Thus, no significant difference was there among the four groups.

On the contrary, the experimental group for boys showed better performance on the post-test. In other words, boys, when taught through ABL showed better performance in the post-test than those who were taught through conventional teaching methods. Throughout the experiment, they were comparatively more engaged and involved. These results of the study support the findings of Harfield et al. (2007) study that showed that in contrast to the conventional methods that make students as mere recipients, activity-based learning encourages students to vigorously contribute to the learning activities. The findings of the current study are also in alignment with Zahoor-ul-Haq et al.'s (2015) study that showed that ABL comparatively yields better performance in listening activities.

Along similar lines, girls who learned through ABL scored significantly better in the postlistening test than those instructed through conventional teaching methods. The study's findings confirmed Krashen's (2003) views who asserted that during the learning process pupils play a dynamic part. According to Krashen (2003), a relaxed environment improves language and literacy and also provides an appropriate level of challenge to connect as well as inspire students. Moreover, the findings of the current study are also in conformity with the Zahoor-ul-Haq et al. (2015) study that concluded that $\mathrm{ABL}$ of listening skills was more engaging and productive for students.

The study also showed that when the experimental groups of girls and boys were compared, no significant difference was found between them. Students in both groups improved their listening performance. It appears that learning through an activity-based method has proved to be significantly better in learning and developing listening skills. This is perhaps because of the variety of activities that engaged and involved students in the study.

\section{Conclusions}

The study concludes that activity-based learning is more engaging for boys as they comparatively participated more actively. Students were careful listeners throughout the process because the activities were planned in such a way that caught the attention of the students. On the other hand, conventional language teaching did not prove to be motivating for the students as they did not show any interest in listening. This as a result produced no productive outcome.

Similarly, girls in the experimental group also took a keen interest in the listening activities that were specifically designed to involve them. As a result, they performed better in the past-test. However, girls in the control group as compare to the experimental group did not perform well. This was perhaps because of the traditional method of teaching that hardly catches the interest and engagement of the students.

Furthermore, it was also found that both boys and girls performance in the post-test of experimental groups was the same. Hence, girls and boys who learned through activity-based leaning had similar achievement in the listening skills.

\section{Recommendations}

The following recommendation has been made:

1. The government should implement the curriculum that employs activity-based learning. This should be followed strictly because routine teaching methods are not fulfilling the needs of teaching and learning in the $21^{\text {st }}$ century.

2. Textbook writers should develop textbooks that consist of interesting activities because normally teachers are reluctant to develop activities for the lesson themselves. This will 
facilitate teachers with readymade activities as most of the teachers in Pakistan are not well trained to create such tasks.

3. Teachers are required to be well trained in developing challenging activities. To enable them, workshops should be conducted during vacations.

4. The professional teacher courses should encourage activity-based learning. In this way, students and teachers will be practically involved in developing activities.

5. The assessment system for language learning should be revised in Pakistan as it focuses only on reading and writing and ignores the listening and speaking areas altogether.

\section{References}

Abdelhamid, T. S. (2003). Evaluation of teacher-student learning style disparity in construction management education. Journal of Construction Education, 8(3), 124-145.

Cambell, D. T \& Stanley, J. C. (1963). Experimental and quasi-experimental designs for Research. Boston, MA: Houghton Mifflin.

Cabral, L. (2006). Twenty-first-century skills for students: Hands-on learning after school builds school and life success, New Directions for Youth Development, 110. Maiden, MA: Wiley InterScience.

Churchill. D. (2003). Effective design principles for activity-based learning: the crucial role of 'learning objects' in Science and engineering education. Retrieved from http://www.learnerstogether.net/PDF/Effective-Design-Principles. Pdf on 10 Oct, 2011.

Chickering, A. W. \& Gamson, Z. F. (1987). Seven Principles for Good Practice in Undergraduate Education. The Wingspread Journal, 9 (2), See also AAHE Bulletin, March 1987.

Domin. D. S. (2007). Students' perceptions of when conceptual development occurs during laboratory instruction. Chemistry Education Research and Practice, 8 (2), 140-152.

Edward, N.S. (2001). Evaluation of a constructivist approach to student induction concerning students' learning styles. European Journal of Engineering Education, 26(4): 429-40.

Ellis, R. (2010). Second language acquisition, teacher education, and language pedagogy. Language Teaching, 43, 182-201. Doi: 10.1017/S0261444809990139

Hake, R. R. (1998). Interactive-engagement versus traditional methods: A six-thousand-student survey of mechanics test data for introductory physics courses. American Journal of Physics, 66(1), 64-74.

Harfield, T., Davies, K., Hede, J., Panko, M., and Kenley, R. (2007). Activity-based teaching for United New Zealand construction students. Emirates Journal for Engineering Research, 12 (1): $57-63$.

Hein, G. (1991). Constructivist Learning Theory. Retrieved from http://www.exploratorium. Edu/IFI /resources / constructivistlearning.html. On 19 Nov, 2011

Hull, D. (1999). Teaching Science Contextually. Retrieved from: http://www.cord.org/uploadedfiles/ Teaching_Science_Contextually.pdf on 04 Dec, 2011.

Hug, B., Krajcik, J. S., \& Marx, R. W. (2005). Using innovative learning technologies to promote learning and engagement in an urban science classroom. Urban Education, 40(4), 446-472.

Kerlinger, F. N. (1973). Foundations of behavioral research. New York, NY: Holt, Rinehart \& Winston.

Khurram, B. A. (2007). Case Study of Organization of Teaching of English in a Public Sector University of Pakistan. This case study formed part of a report that was submitted to the National Committee of English, Higher Education Commission, and Pakistan.

Kolb, D. A. (1984). Experiential learning: Experience as the source of learning and development. New Jersey: Prentice-Hall.

Krashen, S. (2003). Explorations in language acquisition and use. Portsmouth, NH: Heinemann.

Kurita, T. (2012). Issues in second language listening comprehension and the pedagogical Implications. Accents Asia, 5(1), 30-44.

Murray, P., Donohoe, S., and Goodhew, S. (2004). Flexible learning in construction education: a building pathology case study. Structural Survey, Vol. 22(5) 242-250.

Oxford, R. L. (2001). "Language learning styles and strategies". In M. Celece-Murcia (Ed.), Teaching English as a Second or Foreign Language (3 Ed.). Boston: Heinle \& Heinle. Thompson International, pp. 359-366. 
Paik, J. (2008). "Learning English, imagining global": The narratives of early English education experiences in South Korea. The International Journal of Learning, 15(10), 71-78.

Panko, M., Kenley, R., Davies, K., Piggot-Irvine, E., Allen, B., Hede, J. and Harfield, T. (2005). Learning styles of those in the building and construction sector. Report for Building Research New Zealand, Inc. Unitec New Zealand, Auckland

Prince, M. (2004). Does active learning work? A review of the Research retrieved fromhtp:/ctlt.jhsph.edu/resources/views/content/files/150/Does_Active_Learning_Work.pd Fon 03 Jan, 2012.

Richards, J. C. (2005). Second thoughts on teaching listening. RELC Journal, 36, 85-92. DOI: $10.1177 / 0033688205053484$

Suydam, M. N., \& Higgins, J. L. (1997). Activity-based learning in elementary school mathematics: Recommendations from research. Columbus, Ohio: ERIC/SMEE.

Swain, M. (1995). Three functions of output in second language learning. In G. Cook \& B. Thompson, C.B., \& Panacek, E.A. (2006). Research study designs: Experimental and quasi Experimental. Air Medical Journal, 25(6), 242-246.

Wilson, J. J. (2008). How to teach listening. Essex: Pearson Education.

Underwood, M. (1989). Teaching listening. Addison-Wesley Longman Ltd.

Vandergrift, L. (2007). Recent developments in second and foreign language listening Comprehension research. Language Teaching, 40, 191-210. DOI: 10.1017/S02614448070043 38

Vandergrift, L., Goh, C. (2012). Teaching and Learning Second Language Listening. New York: Taylor \& Francis.

Zahoor-ul-Haq; Khan, A., \& Tabassum, R. (2015). Effect of ABL method on students' Performance in listening skills at Grade-VI. Journal of Humanities \& Social Sciences (Pakistan), 23 (3), 95-108.

Zohrabi, M., Sabouri, H., \& Behgozin, M. (2015). The Impact of pre-listening activities on Iranian EFL learner's listening comprehension of authentic English movies. International Journal on Studies in English Language and Literature (IJSELL), 3(2), 42-56. 